INTERNATIONAL JOURNAL OF RESEARCHES IN BIOSCIENCES, AGRICULTURE AND TECHNOLOGY (C) VISHWASHANTI MULTIPURPOSE SOCIETY (Global Peace Multipurpose Society) R. No. MH-659/13(N) www.vmsindia.org

\title{
ANNUAL CHANGES IN FOLLICLE STIMULATING HORMONE AND TESTOSTERONE IN MALE INDIAN FRUIT BAT Rousettus leschenaulti (DESMEREST)
}

\author{
A. S. Masram \\ L. A. D. and Smt. R.P. College for women Nagpur -440010 \\ amg123321@gmail.com
}

\begin{abstract}
:
Little is known about the reproductive endocrinology of the male fruit bat Rousettus leschenaulti except that adult males show double peaks in their testicular activity corresponding to the two pregnancy cycles of the female.First peak occurs during February - March and second occurs during October-November. The levels of Follicle stimulating hormone (FSH) and Testosterone (T) were measured in sera of 36 male fruit bats over a period of 12 months. Result showed that concentration of FSH and T were increased significantly $(\mathrm{P}<0.05)$ during OctoberNovember, February and March as compared to other months of the year. These results indicate that the changes due to breeding season affects the activity of the hypothalamic - testicular axis leading to a decrease or increase these hormones.
\end{abstract}

Keywords: fruit bat, testosterone, follicles stimulating hormone.

\section{Introduction:}

Although Chiropterans are the second largest order of mammals, detailed reproductive patterns and their associated endocrine characteristics have been documented only in a few species (Krutzsch and Crichton, 1990; Bernard et al., 199a; Singh and Krishna, 2000).

Testosterone is the hormone responsible for spermatogenesis and sexual behavior, thus the seasonal pattern of testosterone secretion could limit the male reproductive efficiency during some periods of the year (Todini et al. 2007). FSH hormone has important role in the regulation of spermatogenesis, FSH secretion is under regulation by gonadal feedback effects (Araki et al., 2000), on the other hand, FSH secretion is influenced by both gonadal steroids and non steroidal factors referred to as inhibin (D'Occhio et al. 1982). Testosterone is likely to be the most potent gonadal factor regulating FSH secretion (Araki et al., 2000). Testosterone and FSH are required to obtain full reproductive potential. In the testis somatic sertoli cells transducer signals from testosterone and FSH into the production of factors that are required for sperm maturation (Walker and Cheng, 2005). Keeping in view the peculiar breeding characteristics of male Rousettus and since little informations are available concerning the various aspect of endocrine pattern in male fruit bat in Central India, this study was conducted, to throw some light on the serum levels of FSH and Testosterone in different periods of the year.

\section{Material and Methods: Breeding Habits}

The Indian fruit bat, Rousettus leschenaulti shows a peculiar breeding cycle. Adult males show double peaks in their testicular weight corresponding to the two pregnancy cycles of the female. The first peak occurs during February-March and the second during October-November (Gopalakrishna and Choudhary, 1977).

\section{Collection of animals}

The specimens of Rousettus leschenaulti were collected with the help of mist net placed at the entrance of an underground mine of Mansar / Kandri near Nagpur, Maharashtra (20 ${ }^{\circ} 92 " \mathrm{~N}$ $\left.78^{\circ} 95^{\prime \prime} \mathrm{E}\right)$. Time of collection, body mass, wing span, length of forearm and other salient features of each specimen were maintained in the field diary. The size of testes were estimated by palpating the longest axis of the testis and measuring this distance with callipers, similarly the width was also measured and then each male was transferred to an individual comfortable cage. These traps were transported to the RTM Nagpur University Laboratory. Minimum noise, human exposure and handling were employed to minimize capture stress and excitement. For each sampling, three bats were used.

\section{Blood sampling}

The bats were held in hands and no anesthesia was used at the time of sample collection. $2 \mathrm{ml}$ of blood was collected into sterile tube with no anticoagulants (neither EDTA nor heparin) after puncturing a wing vein. After blood sampling each bat was released. The blood left to clot then centrifuged at 3000 $\mathrm{spm} / 10$ minutes, sera obtained were kept frozen $\left(-20^{\circ} \mathrm{C}\right)$ until used for hormonal determination. FSH and Testosterone activity was measured by Chemiluminescent microparticle immunoassay (CMIA)from Abbotte on the Architect ci8200(Abbotte laboratories diagnostics IL,USA). 
The data was analyzed statistically, standard errors were calculated, on the basis of which graphs were plotted to establish a relationship if any.

\section{Observations:}

Table. 1-

\begin{tabular}{|c|c|c|c|c|c|c|}
\hline $\begin{array}{l}\text { Specimen } \\
(\mathrm{n}=3)\end{array}$ & $\begin{array}{l}\text { Date of } \\
\text { collection }\end{array}$ & $\begin{array}{l}\text { Body } \\
\text { weight }(g)\end{array}$ & $\begin{array}{l}\text { Size of } \\
\text { Testis } \\
\text { (cm) }\end{array}$ & $\begin{array}{l}\text { Testosterone } \\
(\mathrm{ng} / \mathrm{ml})\end{array}$ & $\mathrm{FSH}(\mathrm{U} / \mathrm{L})$ & Reproductive status \\
\hline Male & $8 / 1 / 2013$ & \begin{tabular}{|l|}
$111.33 \pm$ \\
1.86
\end{tabular} & $\begin{array}{ll}2.47 & \pm \\
0.03 & \end{array}$ & $10.27 \pm 0.05$ & $9.50 \pm 0.12$ & Active male \\
\hline Male & $6 / 2 / 2013$ & \begin{tabular}{|l|}
$113.33 \pm$ \\
1.67
\end{tabular} & $\begin{array}{ll}2.60 & \pm \\
0.06 & \end{array}$ & $16.50 \pm 0.04$ & $15.3 \pm 0.03$ & Active male \\
\hline Male & $9 / 3 / 2013$ & \begin{tabular}{|l|}
$128.00 \pm$ \\
1.53
\end{tabular} & $\begin{array}{ll}2.90 & \pm \\
0.10 & \end{array}$ & $18.70 \pm 0.04$ & $15.0 \pm 0.06$ & $\begin{array}{l}\text { Male active spermatogenesis }+ \text { Leydig } \\
\text { cells active Mating period (Peak- } 1 \text { ) }\end{array}$ \\
\hline Male & $8 / 4 / 2013$ & $\begin{array}{l}100.00 \pm \\
2.89\end{array}$ & $\begin{array}{ll}2.17 & \pm \\
0.17 & \end{array}$ & $9.70 \pm 0.12$ & $7.8 \pm 0.09$ & Active male \\
\hline Male & $8 / 5 / 2013$ & \begin{tabular}{ll|}
98.00 & \pm \\
0.58 &
\end{tabular} & $\begin{array}{ll}2.03 & \pm \\
0.09 & \end{array}$ & $5.73 \pm 0.15$ & $5.2 \pm 0.09$ & Male inactive (Quiescence) \\
\hline Male & $9 / 6 / 2013$ & $\begin{array}{|ll|}95.00 & \pm \\
2.65 & \end{array}$ & $\begin{array}{ll}1.96 & \pm \\
0.07\end{array}$ & $3.13 \pm 0.19$ & $5.0 \pm 0.12$ & Quiescent male \\
\hline Male & $9 / 7 / 2013$ & $\begin{array}{|ll|}93.00 & \pm \\
2.52 & \\
\end{array}$ & $\begin{array}{|ll|}1.83 & \pm \\
0.04 & \end{array}$ & $2.87 \pm 0.09$ & $4.9 \pm 0.12$ & Quiescent male \\
\hline Male & $6 / 8 / 2013$ & $\begin{array}{|ll|}70.67 & \pm \\
0.67 & \\
\end{array}$ & $\begin{array}{ll}1.20 & \pm \\
0.15 & \end{array}$ & $2.73 \pm 0.10$ & $5.3 \pm 0.09$ & Male inactive (Quiescence) \\
\hline Male & $4 / 9 / 2013$ & $\begin{array}{|ll|}71.00 & \pm \\
1.0 & \\
\end{array}$ & $\begin{array}{ll}1.03 & \pm \\
0.03 & \end{array}$ & $6.23 \pm 0.15$ & $6.0 \pm 0.09$ & Recrudescent male \\
\hline Male & $6 / 10 / 2013$ & $\begin{array}{l}100.67 \pm \\
5.21\end{array}$ & $\begin{array}{ll}2.13 & \pm \\
0.19 & \end{array}$ & $14.60 \pm 0.08$ & $14.9 \pm 0.18$ & Active male \\
\hline Male & $9 / 11 / 2013$ & \begin{tabular}{|l|}
$121.67 \pm$ \\
1.67
\end{tabular} & $\begin{array}{|ll|}3.07 & \pm \\
0.07 & \end{array}$ & $18.37 \pm 0.15$ & $15.2 \pm 0.06$ & \begin{tabular}{|lcr} 
Active $\quad$ male & showing complete \\
spermatogenesis & mating period (peak-2)
\end{tabular} \\
\hline Male & $11 / 12 / 2013$ & $\begin{array}{|ll|}99.00 & \pm \\
2.08 & \\
\end{array}$ & $\begin{array}{ll}2.33 & \pm \\
0.17 & \end{array}$ & $8.73 \pm 0.07$ & $8.4 \pm 0.06$ & Active male \\
\hline
\end{tabular}

n Body weight(g) $\backsim$ Size of Testis $(\mathrm{cm}) \backsim$ Testosterone $(\mathrm{ng} / \mathrm{ml}) \backsim$ Lactate dehydrogenase(U/L)

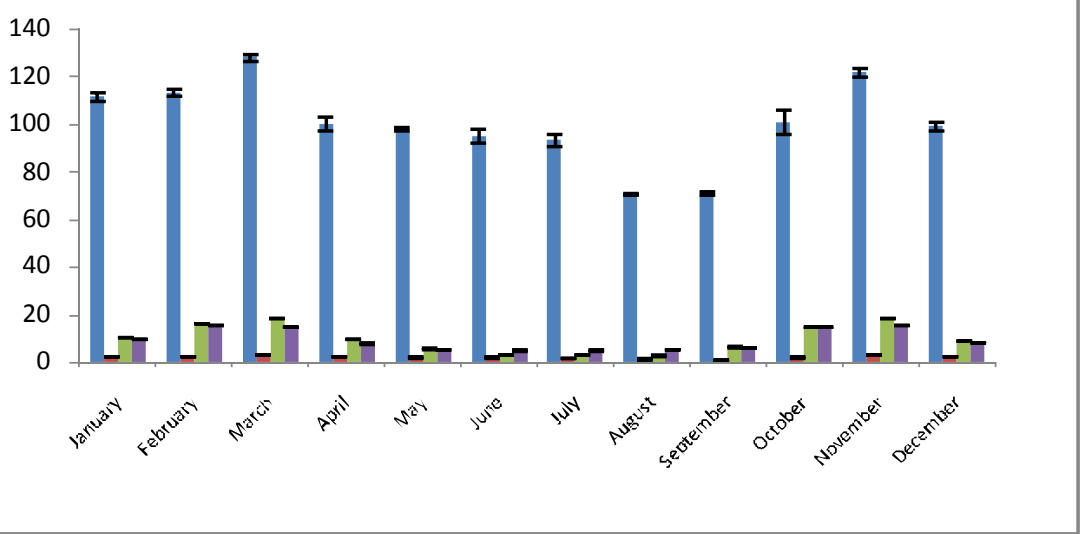

Figure. 1: Annual variations in body weight, size of testis, concentration of serum testosterone and follicle stimulating hormone(FSH) in male fruit bat Rousettus leschenalti

\section{Results and Discussion:}

The body weight, testis size, serum testosterone and FSH levels in the male $R$. leschenaultia collected from January 2007 to December 2007 covering both the breeding periods are depicted in the Table- 1 and bar diagram (fig. 1) have been drawn to show the correlation.
For the present study evaluation of above mentioned two parameters were performed throughout the annual cycle, the observed data is tabulated in table-1 with related bar diagram. (Fig-1). 
appears to be associated with the end of breeding period. The short peaks during the months September, December, January (range $7.67-10.27 \mathrm{ng} / \mathrm{ml}$ ) are consistent with the recrudescence period. The higher values of testosterone during breeding season strongly support the nation that hyperandrogenism to gonadotropin signaling. Similar to the testosterone concentration the concentration of FSH varies. Thus higher ranges (14.9 to 15.2 and 15.0 to $15.3 \mathrm{mIU} / \mathrm{ml}$ ) of FSH concentration are registered during breeding period. On the contrary decline in FSH concentration in rest of the months suggest functioning of the endocrine process.

Hormonal changes obtained in this study (FSH and Testosterone) indicate that there is a significant $(\mathrm{P}<0.05)$ increase in serum FSH and testosterone levels in February-March and October-November which happens to be its breeding season.

The perusal of literature revealed that, testosterone showed a strong correlation with masses of testis and accessory sex glands while androstenedione showed strong correlation with the body mass (Singh and Krishna, 2000). The present findings are also in accordance with previous findings in non-hibernating bats as described in Rhinolophus capensis (Bernard, 1986); in Scotophillus heathi (Singh and Krishna, 1996); in Pteropus vampyrus and pteropus polio cephalus (McGuckin and Blackshaw, 1991, a, b; Martin et al., 1995), but not as in the hibernating bats (range 2288ng/ml) Nyctallus noctula (Racey, 1974); Pipistrellus pipistrellus (Racey and Tam, 1974). The mean body weight of noctules and the mean weight of their testes and accessory glands of reproduction were higher in hibernating bats suggesting a direct role of testosterone in the process of spermatogenesis and maintenance of testicular size, body weight. This is applicable to Rousettus leschenaulti as the relatively low peaks during the quiescence period (May, June, July, August) is an indicator of no spermatogenic activity. Since FSH hormone has important role in the regulation of spermatogenesis FSH secretion is under regulation by gonal feedback effect (Araki et al., 2000) and hence it has positive correlation between Testosterone and FSH levels. However, other environmental stimuli, such as availability of food and social interaction, may be potential regulators of the seasonality of reproduction (Walkden-Brown et al., 1993; Mani et al. 1996).

\section{Conclusion:}

In conclusion the serum $\mathrm{FSH}$ concentration appears to be correlative to the testosterone concentrations which parallel the known morphological transitions of the testes and body mass. The present study confirm the presence of seasonal variation in FSH and Testosterone concentration and its associated changes in the male. These finding contribute significantly to the wild life reproduction and thereof wildlife protection and behavior ecology studies in the field. These findings also confirm that the male adult Rousettus under natural conditions exhibits characteristics of an annual reproductive cycle.

\section{References:}

AIDD Longford .Abbott laboratories Abbott park.IL USA.2006

Araki, K; Arai K.Y; Watanabe, G and Taya $\mathrm{K}$ (2000): Involvement of inhibin in the regulation of follicle - stimulating hormone secretion in the young adult male goat. J. Androl. 21(4): 558555.

Bernard RTF (1986) Seasonal changes in plasma testosterone concentration and Leydig cell and accessory gland activity in the cape horse shoe bat (Rhinolophus caensis). J. Reprod. Fertil. 78 : 413-422.

Bernard RTF, Bojarski C, Millar RP (1991) Patterns of Leydig cell and $\mathrm{LH}$ gonadotroph activity and plasma testosterone concentrations in the seasonally reproducing Schreibers' longfingered bat (Miniopterus schreibersii). J. Reprod. Fertil. 91 : 479-492.

D'Occhio M.J.; Schanbacher, B.D. and Kinder J.E. (1982) Testosterone feedback on FSH secretion in male sheep. J. Repro. Fert. 66: 699702.

Gopalakrishna A, Choudhari PN (1977) Breeding habits and associated phenomena in some Indian bat Rousettus leschnaulti (Desmerest) Megachiroptera Jour Bombay Nat Hist Soc 74(1) : $1-16$.

Krutzsch PH, Crichton EG (1990) Reproductive biology of the male bent-winged bat, Miniopterus schreibersii (Vesprtilionidae) in southeast south Australia. Acta. Anat. (Basel). 139(2) : 109-125.

Mani A.U., Mckelvey W.A.C. and Watson E.D. (1996) Effect of under nutrition on gonadotropin profiles in non-pregnant, cycling goats. Anim. Reprod. Sci. : 43: 25-33. 
Martin L, Kennedy JH, Little L, Luckhoff HC, O'Brien GM, Pow CST, Towers PA, Waldon AK, Wang DY (1995) The reproductive biology of Australian flying-foxes (genus Pteropus). In : Racey, P.A., Swift, S.M. (Eds.), Ecology, Evolution and Behavior of Bats. Clarendon Press, Oxford, pp. 167 - 184.

McGuckin MA, Blackshaw AW (1991a) Seasonal changes in testicular size, plasma testosterone concentration and body weight in captive flying foxes (Pteropus poliocephalus and P. scapulatus) J.Reprod. Fertil. 92 : 339 - 346.

McGuckin MA, Blackshaw AW (1991b) Mating associated peak in plasma testosterone concentration in wild male grey-headed flying foxes (Pteropus poliocephalus). J. Reprod. Fertil. 92(2) : 347-352.

Racey PA (1974) The reproductive cycle in male notule bat, Nyctalus noctula. J. Reprod. Fertil. $41: 169-182$

Racey PA, Tam WH (1974) Reproduction in male Pipistrellus pipistrellus. Proc. Zool. Soc. Lond. 172 : 101-122.

Singh K, Krishna A (1996) Seasonal changes in circulating serum concentrations in vitro testicular secretions of testosterone and androstenedione productions in the male vespertilionid bat (Scotophilus heathi). J. Exp. Zool. 276 : 42-52.

Singh UP, Krishna A (2000) Seasonal changes in circulating testosterone and androstenedione concentration and their correlation with the anomolous reproductive pattern in the male Indian sheath-tailed bat Taphozous langimanus. J. Expt. Zool. 287 : 54-61.

Todini, L., A. Malfatti, G. M. Terzano, A. Borghese, M. Pizzillo and A. Debenedetti ( 2007): Seasonality of plasma testosterone in male of four Mediterranean goat breeds and in three different climatic conditions. Theriogenology 67:627-631.

Walkden-Brown S.W., Restall B.J. and Henniawatti A. (1993) The male effect in Australian Cashmere goats. 3. Enhancement with buck nutrition and use of Oestrous female. Anim. Reprod. Sci. 32: 69-84.

Walker W.H. and Cheng $\mathbf{J}$ (2005) FSH and Testosterone signaling in sertoli cells. J. society for Reprod. and Fertil. 130: 15-28. 